\title{
ANNOTATION
}

\section{The Ophthalmological Society of the United Kingdom, Jubilee Meeting}

This month sees the fiftieth anniversary of a society, the membership of which may justly be termed the hall-mark of a British ophthalmologist. We offer our hearty congratulations to the precocious stripling, which, born in 1880 , very quickly reached years of discretion, and which after a lapse of fifty years is still the living. force in British ophthalmology.

Our society grew out of informal meetings which took place in the house surgeon's room at Moorfields. In 1880, a meeting was held at Mr. Bowman's house to inaugurate the society. Of those present Sir Thomas Barlow is the sole survivor.

The time was ripe for the undertaking; the ophthalmoscope was aged exactly 29 years; the Moorfields Reports, our own special progenitor, had attained their majority just two years previously, while the Ophlhalmic Review was then only germinating in the brain cells of Professor Priestley Smith and Dr. Grossmann. It was felt that there was room for a society, holding monthly meetings in term time, for the reading of papers, discussions and exhibition of cases, and so the society came into being with the respectable membership at the end of its first year of 140,113 of whom were original members, of whom eleven are happily still with us to-day; and four honorary members: viz., Professors Donders, von Helmholtz, and Stokes, and Dr. Williams of Cincinnati.

Among those who have done most for the society we would mention Sir William Bowman and Mr. Nettleship, our first president and surgical secretary, respectively, and Mr. Adams Frost, who for 20 years was responsible for the care of the library. The Bowman Lecture, founded in 1883, and the Nettleship Prize Medal, founded in 1902, commemorate the former two. The Bowman Library, now housed in the Royal Society of Medicine, is a noble monument to Mr. Frost's untiring work.

At the present time the society has a membership of 531 ordinary and 5 honorary members. A set of the transactions is among the most treasured possessions of the British ophthalmic surgeon. That the society may continue to flourish is the fervent hope of us all. Stet fortuna domus. It is just possible that some of our most junior members may live to see and take part in a centenary celebration. We trust that they will be able to look back over a similar span of well spent years as the survivors of our original members. 